\title{
Study of Orthopedic Deformities in Girls and Boys Receiving the "Educate your Child" Program in the Community of the Municipality of Florida, Province of Camagüey, Cuba
}

\author{
Irma de las Mercedes Muñoz Aguilar*1, Rafael Lázaro Tamarit Medrano ${ }^{1}$ and Nila Guzmán Ruiz² \\ ${ }^{1}$ Faculty of Physical Culture, Cuba
}

${ }^{2}$ Physical Culture, Cuba

*Corresponding author: Irma of Mercedes Muñoz Aguilar, Doctor in Physical Culture Sciences, Faculty of Physical Culture, University of Camagüey, Cuba

\begin{abstract}
This article reports a study carried out with a population of 15 children aged between 4 and 5 years, who receive the "Educate your child" program, in the Community of the Municipality of Florida, province of Camagüey, Cuba, for the determination of the orthopedic deformities that they present; the results corroborate the presence of orthopedic deformities such as: flat feet of physiological character, knees valgas, increase dorsal kyphosis and lumbar lordosis, as well as scoliotic attitudes, all of them susceptible to be corrected by the systematic application of activities in the context of the motor dimension of this program.
\end{abstract}

Keywords: Posture; Preschool Age; Orthopedic Deformities; “Educate Your Child” Program

\section{Introduction}

The child's position must be interpreted as the set of changes that develop from birth and that bring the possibility of new patterns of movement, so it is concluded that both terms posture and movement are inextricably linked [1]. The growing infant organism has morphological and functional characteristics that require a specific organization of the child's way of life, of the work activity, of the environment; in order to create the most favorable conditions for their normal development and eliminate the possibility of harmful influences on health, during teaching and daily life [2].

For that reason, is that in the preschool age must be included among the factors that affect this aspect, the conditions in which the child is educated, i.e. for the formation of the position, acquires a particular importance the process of development of motor habits and the functional morphological state of the main muscle groups [3]. In Cuba, the program "Educate your child" is a noninstitutionalized educational modality for children of preschool age, it covers four dimensions, cognitive, affective, social and motor in each of which activities are developed to stimulate development in each of these areas, this program is developed by a specialized professional staff, called executors, in conjunction with the family in the main role and community participation. In the case of the motor dimension, it is designed according to the principles that govern preschool physical education, including the formation of a correct posture [4-5].

In order to carry out this work, the population of 15 children aged between 4 and 5 years, who receive the "Educate your child" program, 6 male and 9 females, in the Community of the Municipality of Florida was studied. , province of Camagüey, Cuba. By means of the postural test, the orthopedic deformities were determined, the classification of foot deformities is used [6]. We found 9 subjects with physiological or first-degree flat feet, which represents $60 \%$, this type of deformity is only affected muscle tissue, which are also carriers of knees valgas. To check the incidence of this deformity, 
the measurement of the distance between both internal malleoli of the ankles is made, the subject being in standing position with the internal faces of the knees in contact, it is worth noting that none of the values found become pathological (9 centimeters) [7].

So, if corrective exercises are applied, this deformity will have a spontaneous resolution and therefore will not be definitively established in the boy or girl, which means that they will not have to use orthopedic devices to correct them. Regarding orthopedic deformities of the back in the sagittal plane, it was found that 7 subjects representing $77.7 \%$ presented an increase in dorsal kyphosis, while $22.2 \%$ had an increase in lumbar lordosis, which is characteristic indistinctly of the kyphotic and lordotic backs, but it is necessary to point out that said increase, although they wanted to expose in this work are not significant enough to corroborate that one is in presence of both types of back [7].

Regarding orthopedic deformities of the back in the frontal plane, posterior view, 11 subjects were found, representing $73.3 \%$ with presence of scoliotic attitudes. It should be noted that in the case of children of preschool age, it is only possible to speak scoliosis if it is congenital in the second or third degree, which are accompanied by conditions in the bone tissue, but in the case that these are They corrected when the children were asked to put themselves in firm position, they were modified, this fact in these ages is called scoliosis attitudes [8]. The results obtained through the application of the postural test show that all of them present orthopedic deformations studied in other populations of preschool children by Muñoz \& Pérez [9], which confirms that if in the context of the "Educate your child" program, are applied postural activities correctly, these deformities will not be permanently implanted in the organism. Before this result, observations were made to the activities developed by the executors of the "Educate your child" program in conjunction with the family in the community context, finding the lack of systematic postural activities, since interests predominated for the activities of the cognitive dimension.

\section{Conclusion}

The most frequent orthopedic deformities in children who attend the program "Educate your child" of the Community of the municipality of Florida, province of Camagüey are the flat feet of physiological character, knees valgas, increase the dorsal kyphosis and the lumbar lordosis, as well as scoliotic attitudes. Even though the "Educate your child" program as a non-institutionalized educational modality for pre-school children covers four dimensions, cognitive, affective, social and motor, the interests of both the executors and the families predominate, that children develop activities of cognitive type, neglecting those of a motor nature, which includes the formation of a correct posture from those ages.

\section{References}

1. Hernández R (1990) Morfología Funcional Deportiva: Sistema Locomotor. Editorial Científico Técnica, La Habana.

2. Laptev A \& Minj A (1987) Higiene de la Cultura Física y el deporte. Editorial Raduga, Moscú.

3. Popov S (1988) La cultura física terapéutica. Editorial Raduga, Moscú.

4. Ministerio de Educación (2015) Programa para la familia dirigida al desarrollo integral del niño "Educa a Tu Hijo". La Habana, Cuba.

5. Bécquer G (2014) La Educación Física Preescolar: Apuntes. La Habana, Cuba.

6. Álvarez R (1986) Tratado de cirugía ortopédica y traumatología. Editorial Pueblo y Educación, La Habana, p. 150-187.

7. Tamarit R, Muñoz I, Mesa L (2013) Gimnasia Correctiva, Camagüey.

8. García L \& Alonso R (2009) Guías de estudio. Plan “D”. Asignatura Cultura Física Terapéutica y Profiláctica, Editora ISCF, La Habana, Cuba.

9. Muñoz I \& Pérez N (2003) Estudio de las deformidades ortopédicas más frecuentes en niños que asisten al Círculo Infantil Clara Zetquin de la provincia de Camagüey. Simposio de Actividad Física Terapéutica y Educación Especial, La Habana, Cuba.

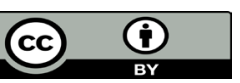

This work is licensed under Creative Commons Attribution 4.0 License

To Submit Your Article Click Here: Submit Article

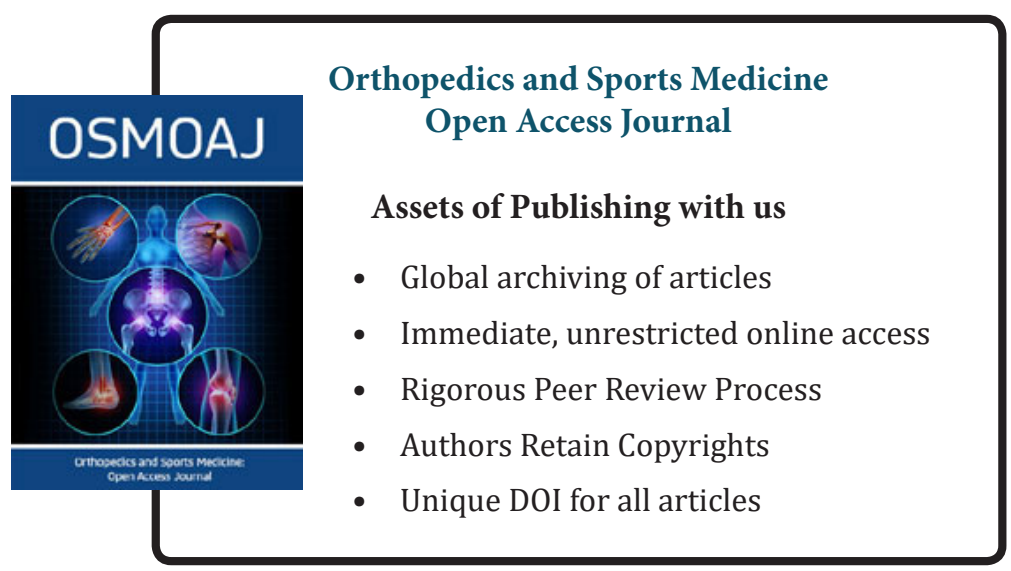

